\title{
The Research on Fit degree Between the Automation Specialty Construction in Profession Colleges and Universities and Personnel training
}

\author{
Jinyao Li \\ Beijing Institute of Graphic Communication, Beijing 102600, China \\ jinyaoli@bigc.edu.cn
}

\begin{abstract}
The new era of economic and social development of the industry characteristics of the university's professional construction and personnel training put forward new requirements. As a distinctive feature of the industry in University of Beijing, Beijing Institute of Graphic Communication should actively adapt to the development of the printing and publishing industry needs, cultivating innovative talents for the industry, promote the school to serve the community, industry's contribution to force. In automation specialty in our college as an example, to fit the industry specialty construction and talents training in university are analyzed and discussed, trying to Industry University's professional construction and talent training enlightenment.
\end{abstract}

Keywords: The industry university; specialty construction; personnel training.

\section{Introduction}

The industry of China is relying on industry development, in the long running process, has formed its own distinctive characteristics, played an important role in promoting the development of the industry, social service [1]. Due to the development of industry and is closely related to the industry, under the influence and guidance in educational philosophy, teachers team construction, personnel training and so on, has become an important base for training talents for the industry, is the industry of science and technology innovation on the strength of[2]. From the point of view of talent cultivation, the industry characteristic university characterized in:

(1) The industry characteristics university personnel training goal is clear, is to meet the urgent need of development of the industry of special talent, outstanding application and practice.

(2) Subjects, professional settings and properties closely attuned to the needs of the development of the industry, and the construction of professional settings to meet the needs of society and employment oriented.

(3) The construction of the teachers in the school is closely around the orientation of running a school.

(4) The main direction of Needless to say, the quality of talents training is the lifeline of higher educational institutions.

At present, there are a series of problems in the construction of teaching staff and the training of talents in the industry:

(1)The "convergence" of talent cultivation is serious, and the characteristics of the school are becoming more and more serious. Many universities have begun to comprehensive universities par, too much emphasis on the development process of a wide range of disciplines, to the neglect of its long form of the characteristics and advantages, the demand for professionals and industry is drifting further and further away, talent training cannot meet the development of the industry of talents are in urgent need of, talent cultivation "trend of assimilation" phenomenon is serious. There is a common problem that the combination of training and demand, theory and practice, the combination of school resources and social resources, resulting in poor adaptability of graduates. The shortage of professional talents has been a key factor to restrict the development of enterprises and the whole industry, which leads to the increasing trend of printing and packing talent gap year by year [3].

(2)The teacher's troop structure is not reasonable the unreasonable structure of teaching staff in the industry is mainly reflected in the unreasonable title structure, and the lack of teachers in the background of industry engineering. The structure of the title of the university industry showing a low proportion of Professor, associate professor and lecturer in proportion to teach high status, due 
to restrictions in the personnel policy in university management mechanism, this situation in the short term unable to alleviate. Analysis of the data showed that the world first-class university teachers title structure was inverted triangle, that the teachers taught in the proportion of very high, close to or more than 50\%; associate professor of accounting for 30\%; the rest of the lecturer and TA. Such a structure, to ensure that the high level of teaching quality and a high level of scientific research work, and ensure each discipline has high level of academic leaders and the backbone of academic (university teachers troop structure optimization and its countermeasures based on the experience of the world first-class university analysis). Since the education reform in colleges, universities and industry enterprises gradually loose, there is no common leadership to collaborative partners to establish a regular system of cooperation. As a result, there is a serious lack of practical experience of teachers. Teachers do not have corresponding engineering background, lack of practical ability, ability of engineering design practice, teachers can't effectively guide of practice [4].

(3)The difficult employment phenomenon. And on the current employment situation, the employment pressure in the industry is also growing. 2013 national college graduates up to 6990000 people, the initial employment rate is only $77.4 \%$. The causes of difficult employment of graduates is structural contradictions, is on the one hand, the graduates employment, on the other hand, industry or regional economic and social development shortage of the skillstype, application type, compound type.

An important problem in the cultivation of talents in colleges and universities is the cultivation of talents in Colleges and universities. Industry university to solve the problem is to change the social demand and professional recruitment, personnel training and student employment respective original array divided state, according to the economic and social development of talent demand relationship of cooperation and, through "market demand" and "resource sharing" integrate the advantages of jointly participate in personnel training and employment competition, realize a win-win situation for the industry the sustainable coordinated development and the social.

Beijing Institute of Graphic Communication is published by the former national news (now belongs to the State Press and Publication Administration) and build the city of Beijing, belonging to the Beijing city full-time ordinary institutions of Higher Education As a printed publication distinctive industry in colleges and universities, to achieve the new requirements of the countries of higher education, profound grasp of the construction of the national press and publication power opportunities, enhance the contribution of school and society, industry, actively participate in the great practice of the "three Beijing",chinese characters in the world city and the zhongguancun national independent innovation demonstration area construction, something under the strategic background of large-scale cultural prosperity and development, adapt to the printing publishing industry development needs and achieve a fundamental change in the mode of development, for the industry to cultivate innovative talents is the meaning of our school is not the unshirkable responsibility. The author thinks that we should think about the school running idea, professional orientation, professional construction and personnel training, and strive for a breakthrough. In this paper, we take the automation of our school as an example, to talk about the professional construction and personnel training in the industry.

\section{Our school of automation specialty orientation}

Our school is an industry characteristics very obvious school, whether from the school layout of disciplines, professional planning perspective to consider or from print publishing industry demand for talent of, our school to the professional should in close connection with the printing and publishing industry. Therefore, the positioning of our school automation professional is as follows:

The professional oriented printing and other related industries, to meet the needs of capital economic construction and social development, cultivating application-oriented talents with control engineering and automation equipment professional comprehensive ability and innovative spirit.

The professional focus on printing, packaging and other related industries, highlighting the students in control engineering and automation equipment research, design and application of basic ability. 


\section{The professional automation graduates of our school to go.}

In all subjects, students' employment in the industry in the proportion of each are not identical, our school has printing engineering, editing and publishing the national specialty very significant industry characteristics like this, there are also a number of automation of this industry in general professional colleges. Therefore, the study of the social needs of the school automation professional and the whereabouts of the graduates are important for the professional construction and personnel training in the industry.

The professional employment mainly consists of the following parts:

(1) Publishing house, printing company

(2) Industry employment, printing, packaging machinery manufacturing industry

(3) Employment; field of automation

(4) Electronic information and computer science

For the first nine graduates (2004--2013) of the employment situation in our school automation professionals have done a detailed statistics, students' employment is mainly concentrated in the following areas:

(1)Publishing company, printing enterprise: about $20 \%$

The main China encyclopedia press, Day Newspaper, Hebei Daily, Shenzhen Daily, Beijing Plant, higher education printing factory, Dongfeng Beijing Ya Chang Group, Shantou city printing Co. Ltd, China petroleum, Sichuan Newspaper Daily Newspaper group printing company.

(2)Printing and packaging machinery manufacturing industry, about $10 \%$

The main printing equipment manufacturing industry of China's leading enterprises, beiren group Qingdao Ruipu electric company, ZhongshanSongde Packaging Machinery Co., Ltd., Weifang Eastern Pml Precision Mechanism Ltd, Shaanxi beiren Co. Ltd., Ningbo Xinda printing machine Co. Ltd., Sichuan Juguang printing equipment company.

(3)Automation professional field: about $20 \%$

The main Siemens, ABB, Beijing shinaitong Electrical Technology Co., Ltd. of Beijing city equipment installation engineering company, Shougang Industrial Company, Beijing heavy machinery factory, Chinese first Institute of Aerospace Science and technology group, Chinese northern broadcasting industry corporation.

(4) Electronic information, computer field: about $25 \%$

The main founder, China information security certification, High German software company, Fuk Road Aerospace Information Technology (Beijing) Co., Ltd., Shenzhen storage Co. Ltd., Beijing Zhitong Wireless Technology Co. 1td.

(5)Graduate School or continue studying abroad, about $15 \%$.

(6) The other: such as civil servants, village officials, free lance, etc., about $10 \%$.

\section{The construction of our school automation professional teachers}

Automation has a total of 17 teachers (which two experimental series of teacher), has been completely meet the teaching needs from the number of people, but the faculty structure unreasonable, this and the previously mentioned the college teachers team structure unreasonable mainly reflected completely consistent. The outstanding problems are:

(1) The title structure is unreasonable, the proportion of senior professional titles is low. The most prominent is the ratio of the professor is too low, only 6\%, the associate professor accounted for $29 \%$, the proportion is low.

(2) Teachers do not have the appropriate industry engineering background. The professional in recent years has introduced 5 Key University Dr., on the one hand, these new teachers academic broad vision, solid theoretical foundation, on the other hand, because it is from school to school, teachers have no corresponding engineering background, practical ability, ability of engineering design needs to be improved. 
According to the specific problems in the construction of teaching staff, the professional teachers have to do a good job in the construction planning and strengthening the construction of teachers, mainly to take the following measures:

(1)The technical personnel in the industry field to participate in the professional construction. On the one hand, the technical staff to participate in the industry field backbone enterprises to participate in the formulation of the training program; on the other hand, the technical staff of the industry field backbone enterprises to teach. Such as the motion control system "the curriculum and printing equipment in the field of international giants Rexroth company cooperation control, please Rexroth company China branch of the engineer and professional teachers teaching; the electric control system with PLC, beiren group cooperation in the field of dragon head enterprise curriculum and chinese printing machinery manufacturing, please beiren group Engineer and professional teachers teaching. The school teachers to teach the theory part, enterprise engineer with a large number of actual cases teaching in engineering application part, through the teaching, make professional teachers a better understanding of the industry, at the same time, students reflect the great harvest.

(2)The practice of young teachers under the factory In order to make no industry engineering background of teachers' understanding and the understanding to the industry, and improve the practical ability, the ability of engineering design, college and automation professional specially formulated planning in the construction of teachers' team, new into the position of young teachers to enter the industry enterprise practice for more than three months, so as soon as possible to the industry understand.

(3)To promote and promote the construction of teachers' team in the discipline construction. Disciplines of automation construction goal is very clear, namely to digital printing equipment key laboratory of Beijing under the printing equipment electrical control technology research center as a platform to gather academic team, the professional teachers as soon as possible into the subject, causes them to personal growth and subject to special industry development closely together.

(4)Actively preparing to introduce to stand in the forefront of the discipline, leading the development of the subject of academic leaders, can lead the automatic chemistry Coda to Beijing city, the focus of the construction of disciplines.

(5)Pay attention to the cultivation of teachers' innovative ability and spirit of cooperation, we must combine theory with practice, which requires teachers to have a very rich experience in practice. The automation profession encourages and initiates in the young backbone teacher to the domestic famous university, the research institute to carry on the study, the academic exchange, the visit or the cooperation research.

(6)Strengthen the construction of teachers' morality. Only by strengthening the construction of teachers' morality, to carry forward the excellent teaching style, in order to enable teachers to actively explore and practice the law of education and teaching, care for students, rigorous Duxue, indifferent to fame and wealth, self-esteem and self-discipline, dedicated to helping students all-round development, with noble morality, personality, learning style education students infected, the healthy growth of a student guide and guide. Due to the outstanding performance in 2012, automation of our school was named the "advanced collective morality".

\section{Conclusion}

With the unique characteristics of the construction of the teachers and the training of talents in the industry, the research on the degree of fit for the construction of the teaching staff and the training of the talents is very necessary. The author thinks that should demand for innovative talents from the industry, also is for the industry personnel training as the starting point, to demand oriented, pushing down industry in colleges and universities of professional construction and teaching staff construction, improve the quality of industry personnel training in colleges and universities. 


\section{References}

[1] Xiang Gao, Wanwei Li and Ying Fang. Study on the connotation of industry orientation of higher education institutes [J].Journal of Shanghai Customs College. 2013(6):106 107.

[2] ShuoFeng, Changzhi Yu and Wei Sun. The main problems and countermeasures of personnel training in the industry of our country [J].Higher agricultural education. 2013(6):26 27.

[3] Changyue Wang. Direct printing industry "talent shortage" [J].Printing Industry Press. 2011 (9):55 56.

[4] YanHan, Wenyin Wang and Keyong Zhang. Research on the construction of teaching staff in Local Engineering Colleges[J].Journal of North Central University (Social Science Edition).2012(3):2 3. 